\title{
Anterior esthetic restoration accompanied by gingivectomy of patient with unesthetic tooth proportion of maxillary anterior teeth: a case report
}

\author{
Sang Yeon Han', Jonghyuk Lee ${ }^{1 *}$, Seok Yeun Choi \\ 'Department of Prosthodontics, College of Dentistry, School of Health Science, Dankook University, Cheonan, Republic of Korea \\ 2Jangbaek Dental Laboratory, Seoul, Republic of Korea
}

The maxillary anterior teeth play an important role in esthetics. The esthetic of maxillary anterior teeth is closely related to tooth morphology and also harmony with gingiva. Precise diagnosis and treatment plan are essential to satisfy patient's demand, and sometimes surrounding soft tissue management is involved to achieve the goal. Gingivectomy can be considered as one method to make esthetic restoration possible. As well as esthetics, function has to be considered in maxillary anterior teeth restoration. Definitive cast of abutment and diagnostic cast waxed up labially were superimposed with model scanner, so can provide former comfortable occlusion. This case report demonstrates functional and esthetic improvements of two patients through gingivectomy and the data of superimposed image of casts. (J Dent Rehabil Appl Sci 2018;34(3):208-17)

Key words: esthetics; gingivectomy; diagnostic wax up; superimposed image of casts

\section{서론}

상악 전치부의 심미는 환자들의 민감도가 매우 높으 며, 이를 만족시키기 위해서는 정확한 진단과 치료계획이 필수적이다. 흔히 상악 전치부의 심미를 만족시키기 위 해서는 pink esthetic과 white esthetic을 모두 고려하여 야 한다. Pink esthetic으로는 치은 건강, zenith line, 치 간유두 형태 등 치은과 관련된 요소를 고려하여야 하며, white esthetic으로는 치축, 상대적 치아 비율, 치아 형태, 절단연 형태 등 치아와 관련된 요소를 고려하여야 한다. ${ }^{1}$

보통의 경우 white esthetic을 수정해주는 것만으로도 만 족할 만한 결과를 얻을 수 있지만, 필요시 주위 연조직에 대한 처치를 동반한 pink esthetic의 개선을 고려해야 할 수 있다. 임상적 치관의 길이가 짧거나 비대칭을 이루는 경

*Correspondence to: Jonghyuk Lee

Professor, Department of Prosthodontics, School of Dentistry, Dankook University, 119, Dandae-ro, Dongnam-gu, Cheonan, 31116, Republic of Korea Tel: +82-41-550-1975, Fax: +82-41-550-0255, E-mail: hyuk928@chol.com Received: April 24, 2018/Last Revision: May 21, 2018/Accepted: June 28, 2018
우 비심미적인 외형을 보일 수 있는데, 이때 연조직 처치로 서 외과적 치관연장술 중 하나인 치은절제술을 고려할 수 있으며 이를 통해 심미적인 보철 수복을 할 수 있다.

미소시 안모와 입술과의 관계도 상악 전치부 심미 에 있어서 중요한 요소이다. 상악 전치부는 미소시 75 $100 \%$ 의 길이가 노출되는 것이 보편적이다. 미소선에 관 해서는, 일반적으로 상악 전치부의 절단연이 하순과 평 행한 것이 좋다. ${ }^{2}$

치아 폭의 비율은 일반적으로 황금비를 따르는 것이 좋으며, 길이와 폭의 비율이 $0.75-0.8$ 을 이룰 때 심미적 이라고 평가된다. ${ }^{3}$ 치은 선과 zenith position은 중절치와 견치는 같은 높이, 측절치는 $1 \mathrm{~mm}$ 하방에 형성되는 것이 심미적이며, 근원심 위치로는 치아의 중앙을 기준으로 중 절치는 $1.1 \mathrm{~mm}$ 원심, 측절치는 $0.4 \mathrm{~mm}$ 원심, 견치는 정

Copyright@ 2018 The Korean Academy of Stomatognathic Function and Occlusion. (c) It is identical to Creative Commons Non-Commercial License. 
중앙에 위치하는 것이 좋다. ${ }^{4}$

본 증례에서는 치아 길이 부조화 및 치아 형태 개선을 주소로 하는 두 환자에 대해 치주 수술을 동반한 보철 수 복을 시행하였다. 진단 납형 모델 분석을 통해 지르코니 아를 코핑으로 하는 전부도재관 수복을 계획하였고, 최 소한의 교합조정을 위해 모델을 스캔, 중첩하여 보철물 을 제작하였다. 두 환자 모두 심미적, 기능적으로 만족하 는 결과를 얻었기에 이를 보고하고자 한다.

\section{증례보고}

\section{1. 증례 $A$ : 반점치 및 치아 형태 이상을 전부 도재 관으로 수복한 증례}

본 증례의 환자는 20 세 여성으로, 앞니가 많이 나와 있 고, 과도한 치은 노출 및 치아 모양과 변색을 개선하고 싶다는 주소로 내원하였다. 의과적 병력은 없었으며, 약 간의 치과 공포증을 가지고 있었다. 환자 상태에 대해 안 모 및 구내 사진, panorama 방사선 사진, 모델 분석을 하 였으며, 이를 통해 미소선, zenith line, 치아 형태 및 변색 정도를 평가하였다.
안모 사진을 평가하였을 때 좌우측 중절치의 길이 부 조화와 부자연스러운 미소선을 관찰할 수 있었으며, 치 아와 안모의 정중선이 약 $1.2 \mathrm{~mm}$ 부조화를 이루는 것을 알 수 있었다(Fig. 1). 구내 사진을 통해 상, 하악 전치부 의 반점치와 비심미적인 치아 형태 및 정중선의 불일치를 볼 수 있으며, 큰 overjet $(5.4 \mathrm{~mm})$, overbite $(4 \mathrm{~mm})$ 을 보 였다(Fig. 2). 상악 전치부의 반점치를 Dean's index ${ }^{5}$ 를 통 해 관찰한 결과 중절치는 Dean's index 3 (Moderate and severe), 측절치와 견치는 Dean's index 2 (Mild)의 범주 를 보이고 있었다. 비대칭적인 zenith line을 보이고 있어

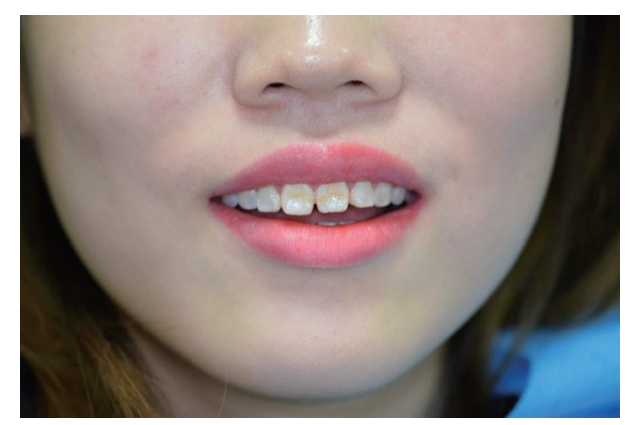

Fig. 1. Preoperative extraoral view.
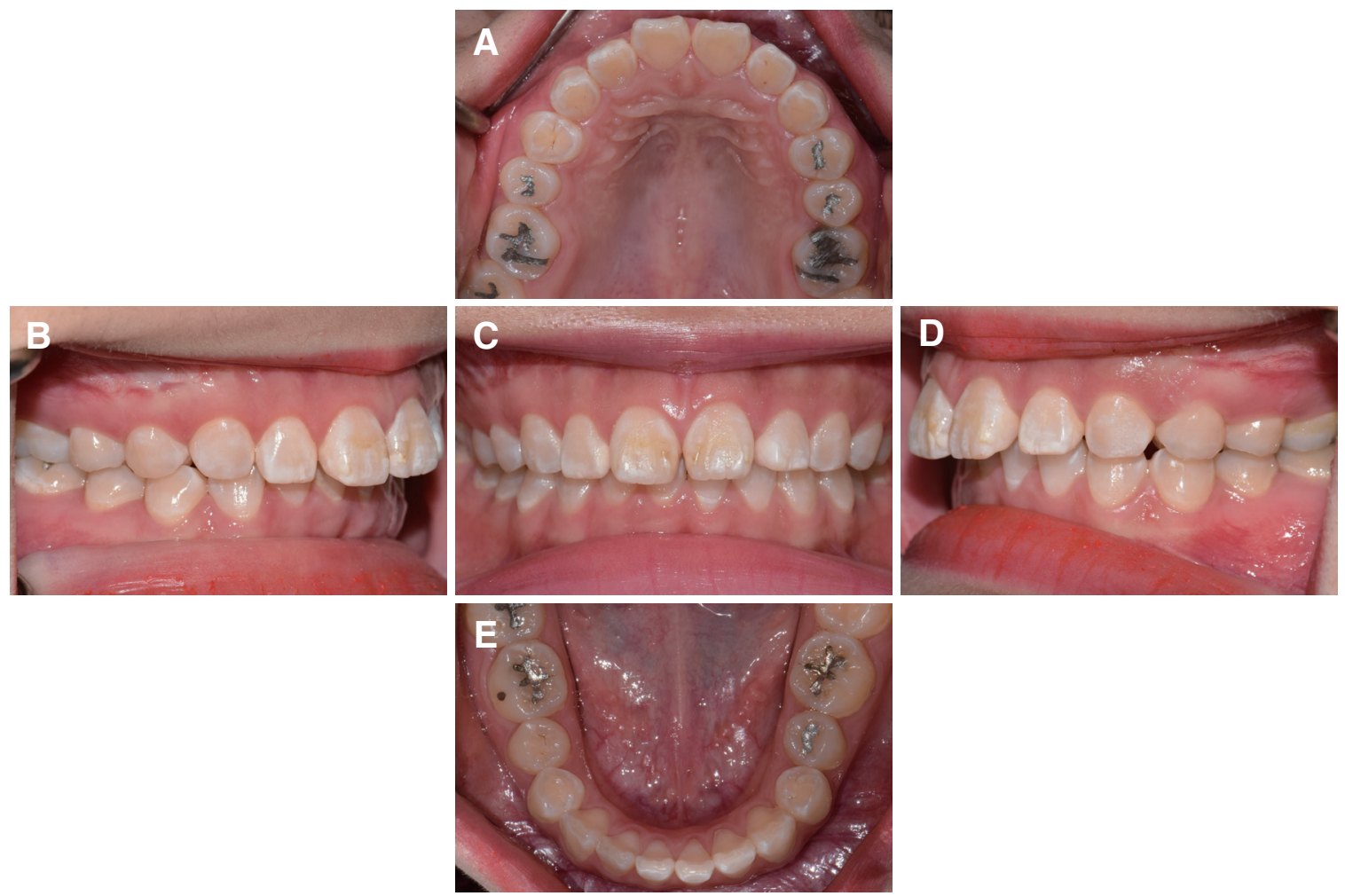

Fig. 2. Preoperative intraoral view. (A) Occlusal view of maxilla, (B) Right lateral view, (C) Frontal view, (D) Left lateral view, (E) Occlusal view of mandible. 


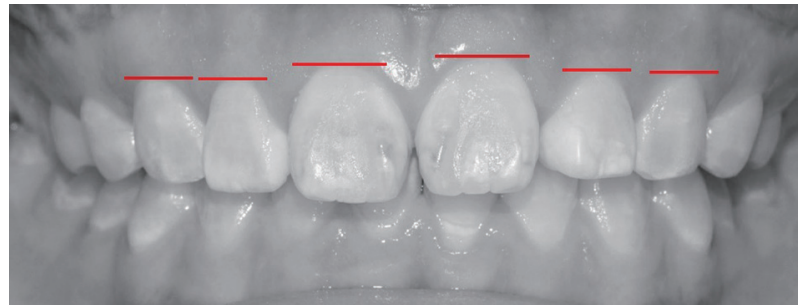

Fig. 3. Zenith of the gingival contour of maxillary anterior teeth.

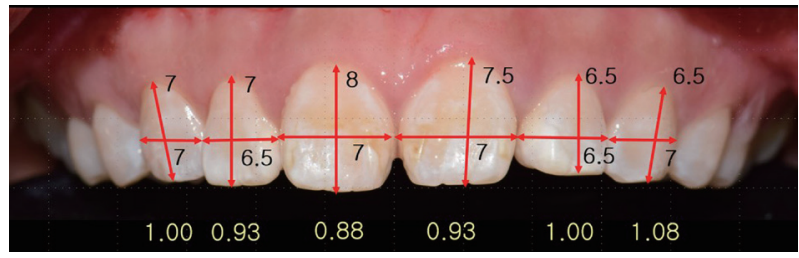

Fig. 4. Analysis of maxillary anterior tooth size and proportion.

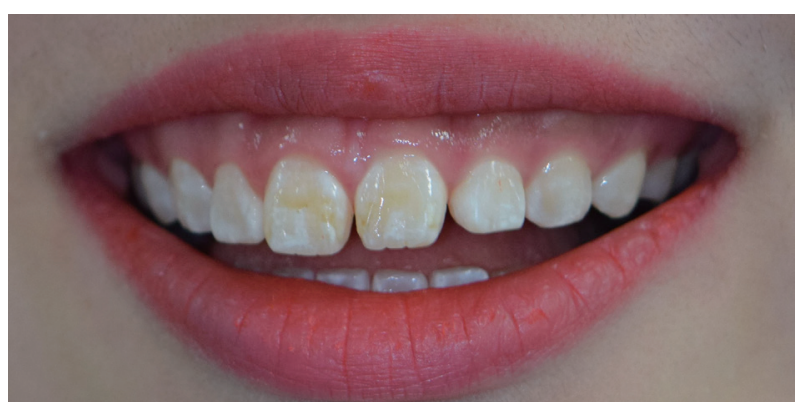

Fig. 5. Extraoral view of smile line.
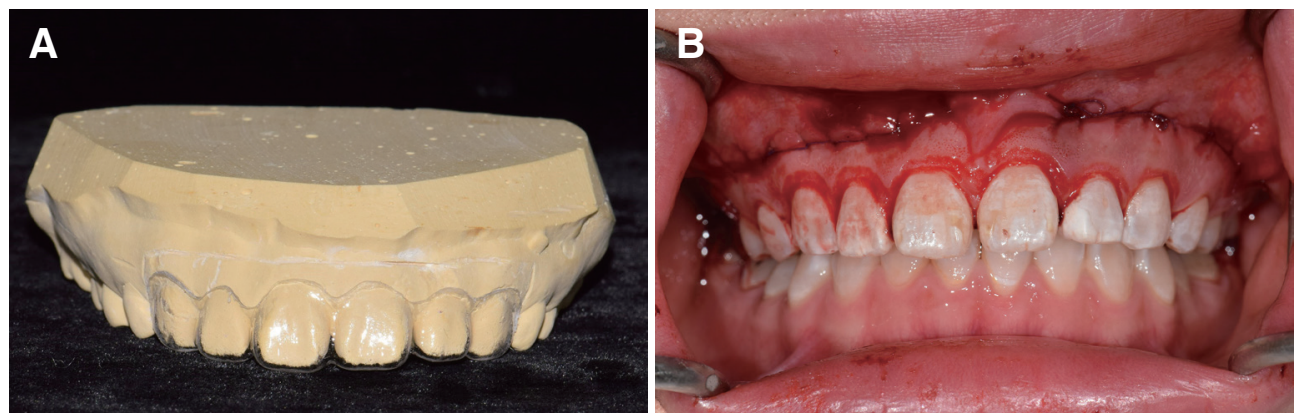

Fig. 6. Gingivectomy and lip repositioning. (A) Surgical splint for gingivectomy, (B) After gingivectomy and lip repositioning.
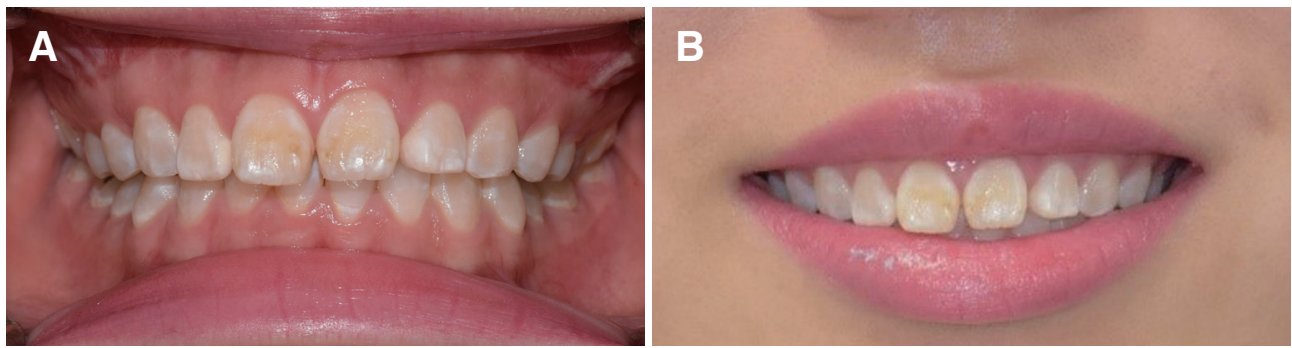

Fig. 7. Intraoral and extraoral view 1 month after periodontal surgery. (A) Intraoral view, (B) Extraoral view. 


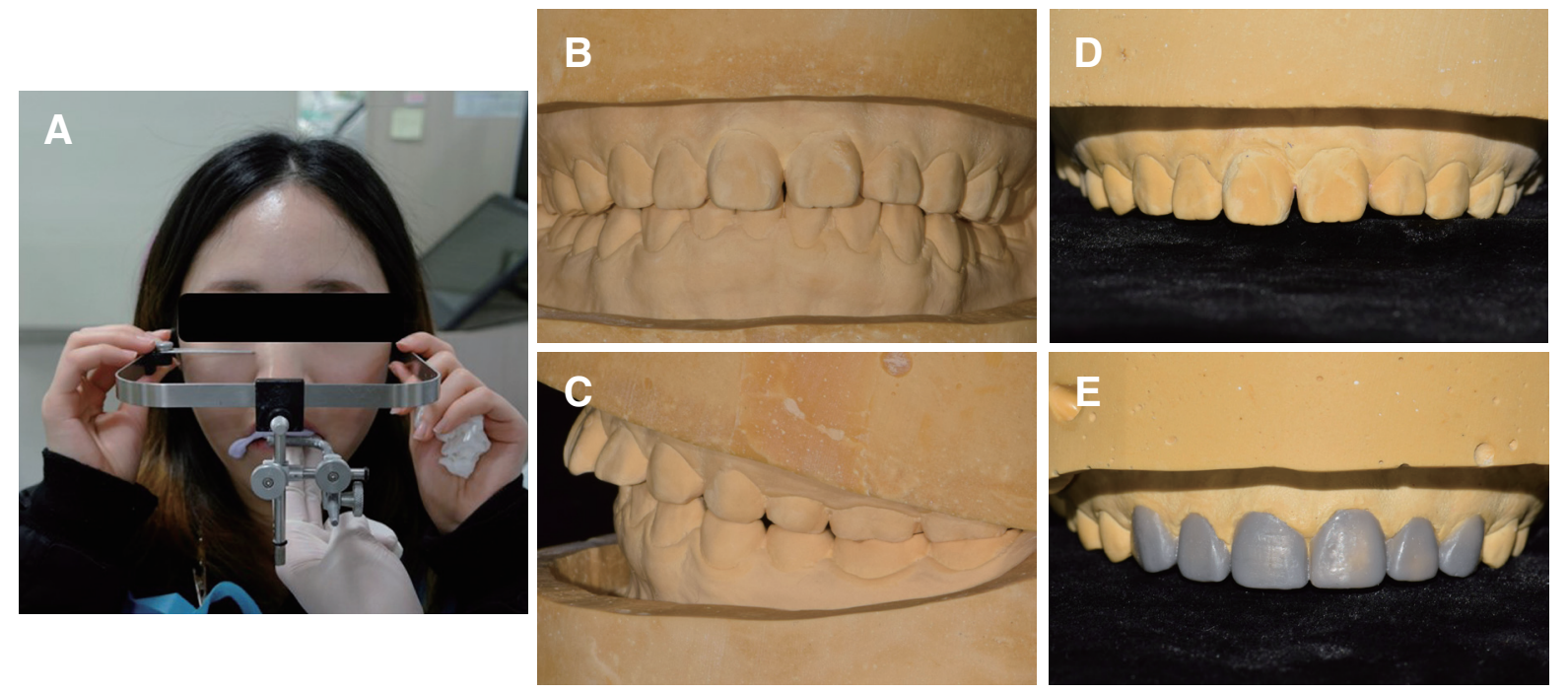

Fig. 8. Diagnostic model fabrication. (A) Face bow transfer, (B) Frontal view of diagnostic model, (C) Lateral view of diagnostic model, (D) Diagnostic model of maxilla, (E) Diagnostic wax-up model of maxilla.
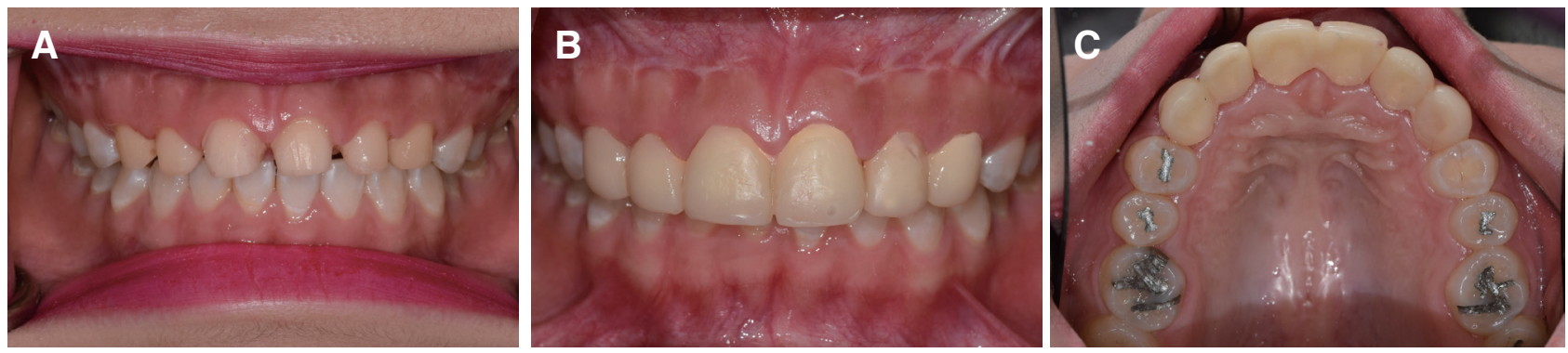

Fig. 9. Intraoral view after tooth preparation and temporary bridge restoration. (A) Tooth preparation, (B) Frontal view of temporary crown, (C) Occlusal view of temporary crown.
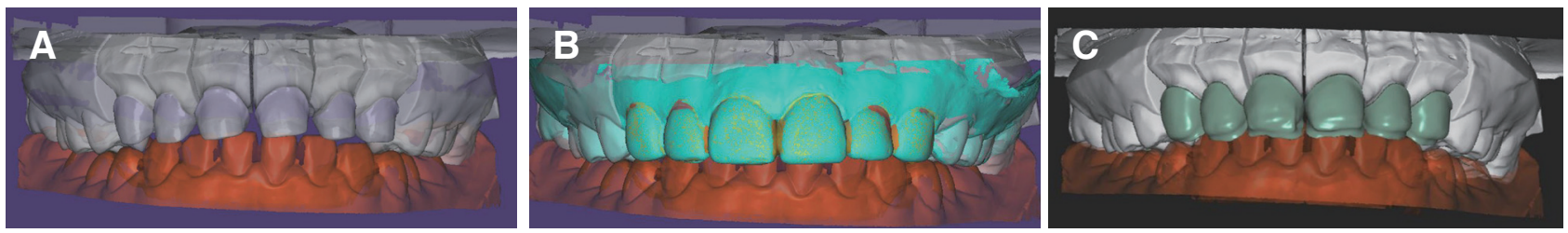

Fig. 10. Model scan and coping design. (A) Model scanned image, (B) Superimposed image of definitive model and wax-up diagnostic model, (C) Coping design image.

순측 삭제를 위한 book index와 구개측, 절단 삭제 를 위한 putty index를 제작하여 치아 삭제를 시행하였 고, 납형 진단모형을 이용하여 임시 수복물로 수복하였 다(Fig. 9). 치아 삭제 후, 이중 압배사를 사용하여 최종 인상을 채득하였으며, 수평면과 정중선을 기록한 악간 관계를 채득하였다. 색조를 평가하기 위해 shade guide (VITA classical shade guide, VITA Zahnfabrik, Bad
Säckingen, Germany)를 이용하였고, shade A2로 결정 하였다. 순면의 심미를 참고하고, 설면의 형태는 그대로 유지하기 위해 모델 스캐너(Exoscan, exocad $\mathrm{GmbH}$, Darmstadt, Germany)와 CAD 소프트웨어(Exocad 6136, exocad GmbH, Darmstadt, Germany)를 이용하 여 모델을 스캔, 디자인하였다(Fig. 10). Milling machine (Yenadent D43, Yenadent, Istanbul, Turkey)을 이용하여 
지르코니아 블록(Lava ${ }^{\mathrm{TM}}$ Zirconia Blocks, 3M, Minnesota, USA)을 가공하여 코핑을 제작하였다. 제작한 코핑 을 시적하였고, 도재(Creation porcelain, Zensen Dental, North Haven, USA)를 축성하여 전부 도재관을 각각 단 일 치관 수복물로 제작하여 이를 구강 내에서 맞춰보았 다(Fig. 11). 치아의 폭/길이 비율이 감소(0.75 - 0.88)한 것을 알 수 있으며(Fig. 12), overjet의 감소 $(4.7 \mathrm{~mm})$ 로 보
다 심미적인 결과를 얻을 수 있었지만, overbite은 일정하 게 유지되었다(Fig. 13). 미소를 평가하였을 때도 부자연 스러운 미소선이 개선된 것을 확인할 수 있었다(Fig. 14). 교합을 평가하였을 때, 치료 전 후에 비슷한 교합 양상을 볼 수 있었고, 최소한의 교합치료만으로 편안한 교합을 얻을 수 있었다(Fig. 15).
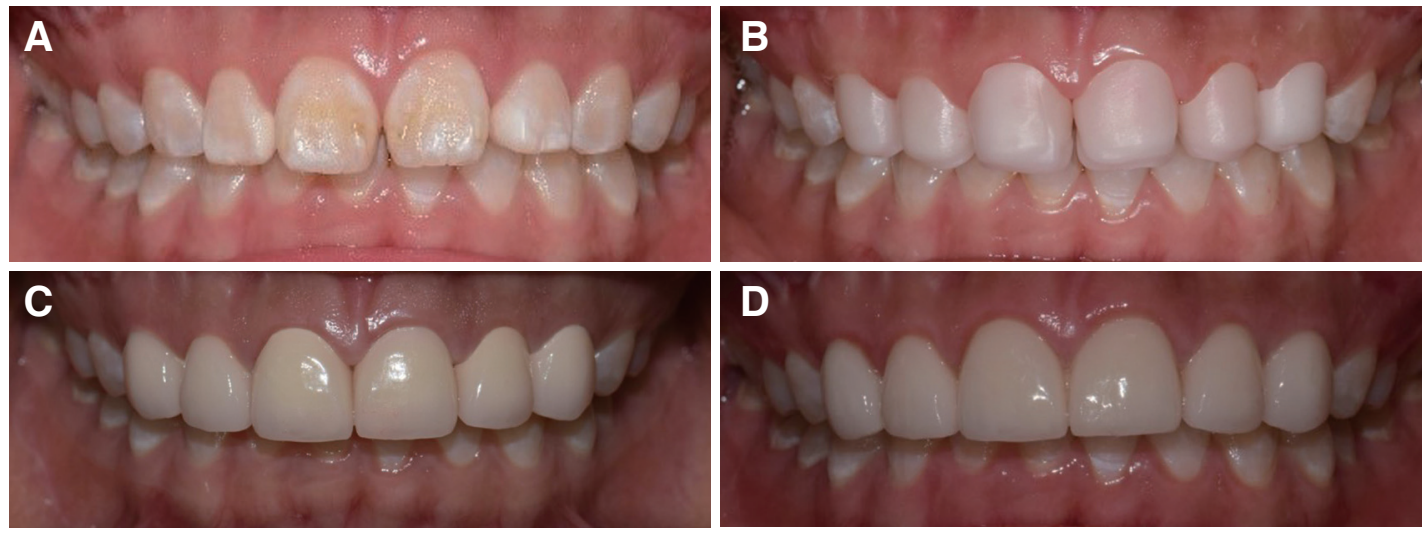

Fig. 11. Intraoral view of coping and final restoration try in. (A) Intraoral view of pretreatment state, (B) Coping try in, (C) Final restoration try in, (D) 1 year after treatment.

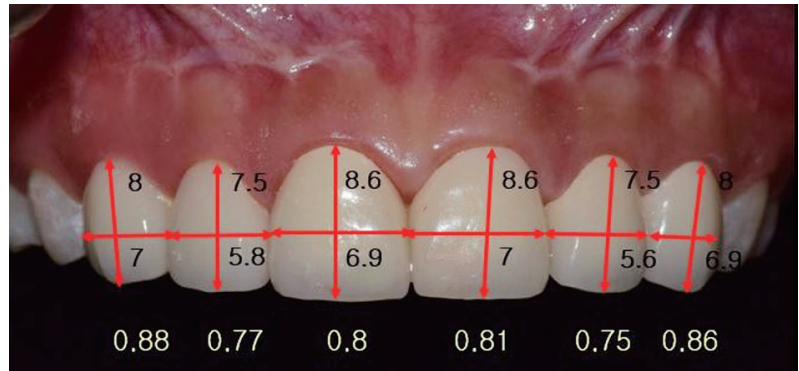

Fig. 12. Analysis of maxillary anterior tooth size and proportion after treatment.
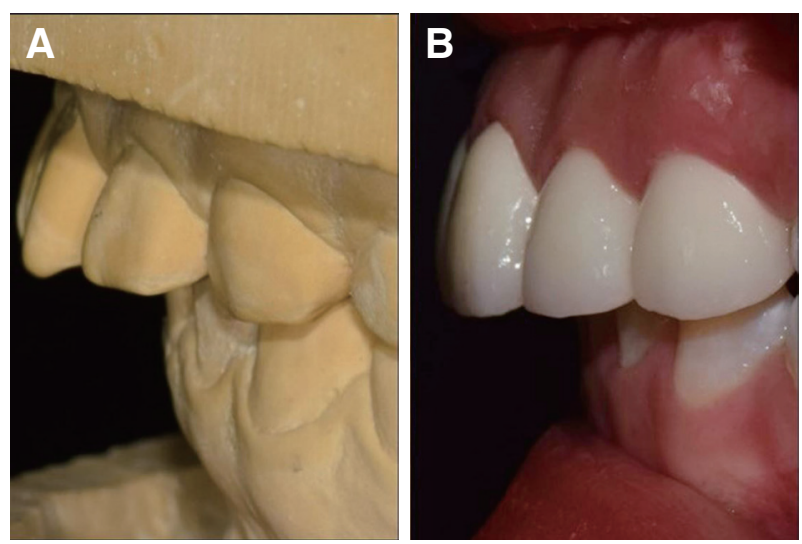

Fig. 13. Analysis of overjet and overbite. (A) Before treatment, (B) After treatment.
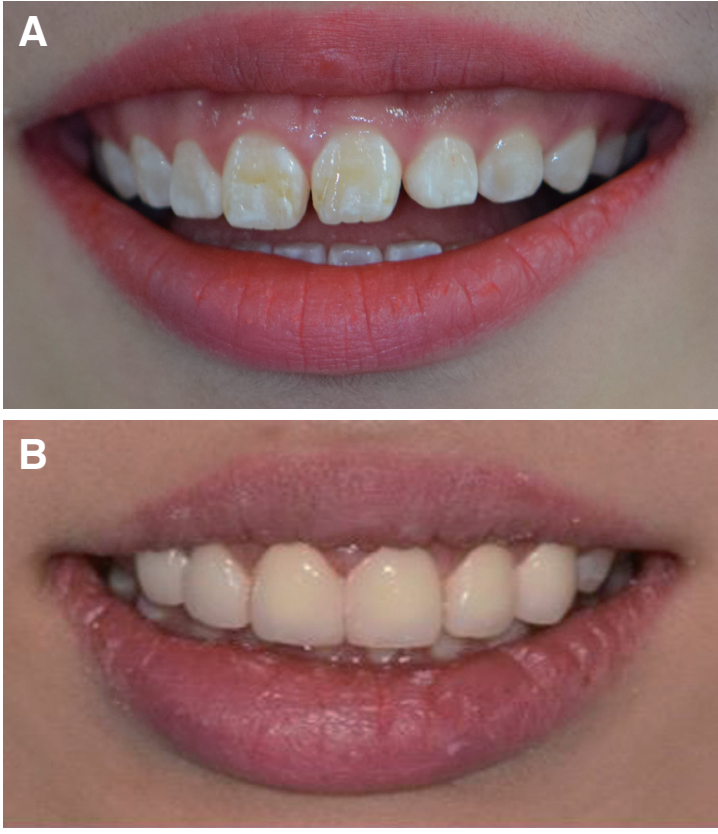

Fig. 14. Analysis of smile line. (A) Before treatment, (B) After treatment. 

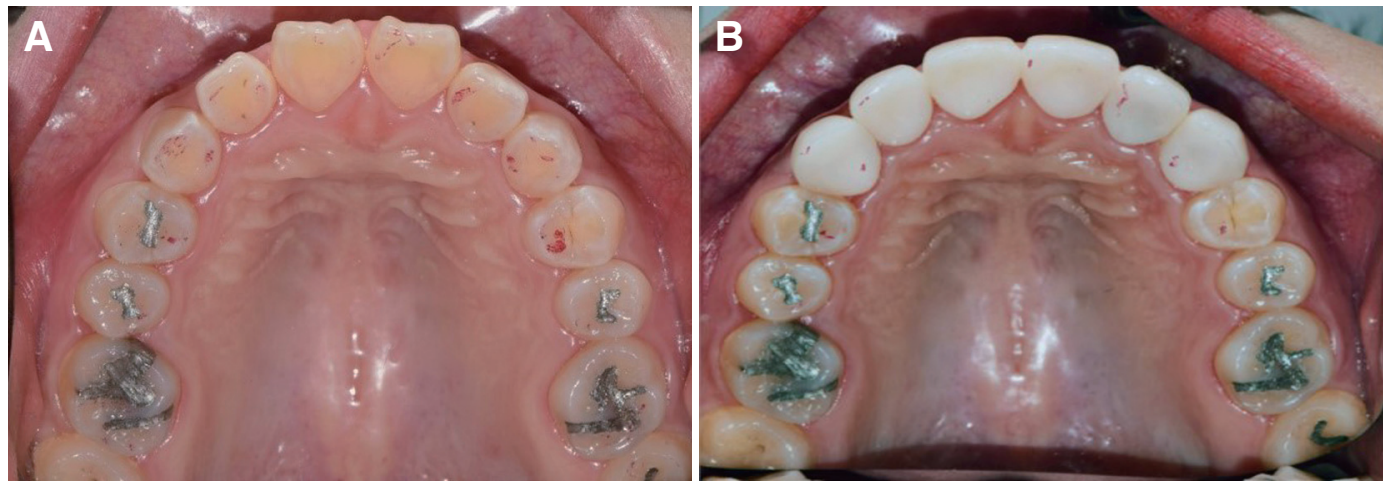

Fig. 15. Intraoral view of occlusion. (A) Occlusion before treatment, (B) Occlusion after treatment.

\section{2. 증례 $\mathrm{B}$ : 치아 길이 부조화와 비심미적 치은을 전 부 도재관으로 수복한 증례}

본 증례의 환자는 40 세 남성으로, 상악 전치부의 저작 시 불편감과 치아 길이 비대칭, 치은의 변색을 주소로 내 원하였다. 의과적 병력은 없었으며, 치과적으로는 \#11, 21 치아를 지대치로 하고 \#12 치아를 가공치로 하는 3 unit cantilever bridge로 수복한 병력이 있었다. 환자 상 태에 대해 구내 사진, panorama 방사선 사진, 모델 분석 을 하였으며, 이를 통해 zenith line, 치아 형태를 평가하 였다.

구내 사진을 평가하였을 때, \#11, 21 치아는 치은염이 존재하였고, 그 상방으로 검은 착색을 볼 수 있었으며, 좌우 측절치 치은선의 심한 비대칭을 관찰할 수 있었다 (Fig. 16).

상악 전치부 치아의 폭/길이 비율을 봤을 때 약간 큰 값을 나타냈으며 $(0.75-0.85)$, 좌우 측절치의 길이 부 조화로 인해 폭/길이 비율 차이가 크게 나타났다(\#12:

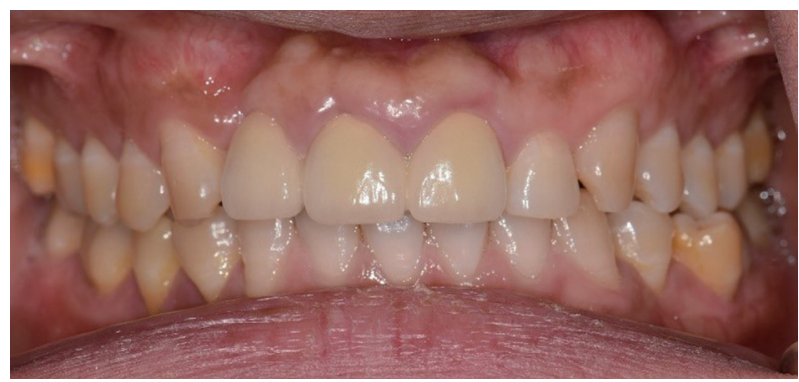

Fig. 16. Intraoral image of frontal view.
0.75, \#22: 0.85).

위의 문제점을 해결하기 위해 치은절제술과 치은박피 술을 동반한 전부 도재관 수복을 계획하였다.

먼저 안궁 이전을 통해 모델 분석을 하였고, splint를 제작, 참고하여 치주수술을 진행하였다. 치주 수술 후 기 존 보철물을 제거하였다. 레진 코어 하방으로 2차 우식이 존재하였으며, 우식 제거 후 \#13 치아를 추가적으로 삭 제하여 4본 임시 고정성 수복물로 수복하였다.

한 달의 치유기간 후 평가를 하였고, \#22 치아의 길이 증가를 통해 좌우 측절치 길이에서 오는 부조화를 개선 하였다(Fig. 17). Putty index를 이용하여 치아 삭제를 하 였고, 색조 평가 후 shade A2로 색조를 결정하였다. 최종 인상을 채득하였고, 지대치 주모형과 납형 진단모형을 모델 스캐너(3 Series, Dental wings, Montreal, Canada) 로 스캔하여 CAD 소프트웨어(DWOS 7, Dental wings, Montreal, Canada)로 중첩, 디자인하여 코핑을 제작하 였다(Fig. 18). 첫 번째 증례와 동일하게 milling machine (Yenadent D43, Yenadent, Istanbul, Turkey)을 이용하

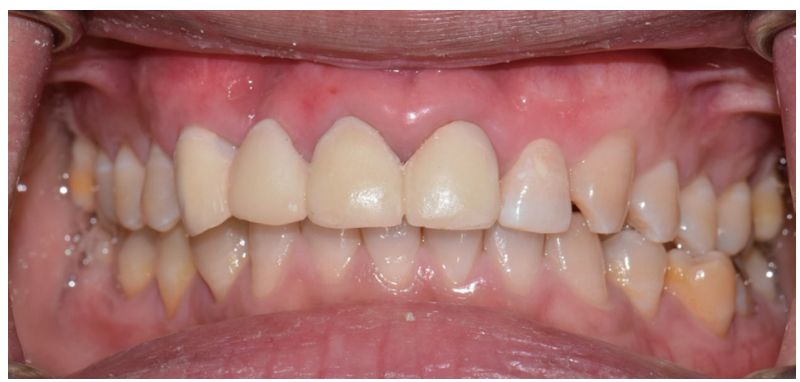

Fig. 17. Intraoral image of frontal view, 1 month after periodontal treatment and temporary restoration. 


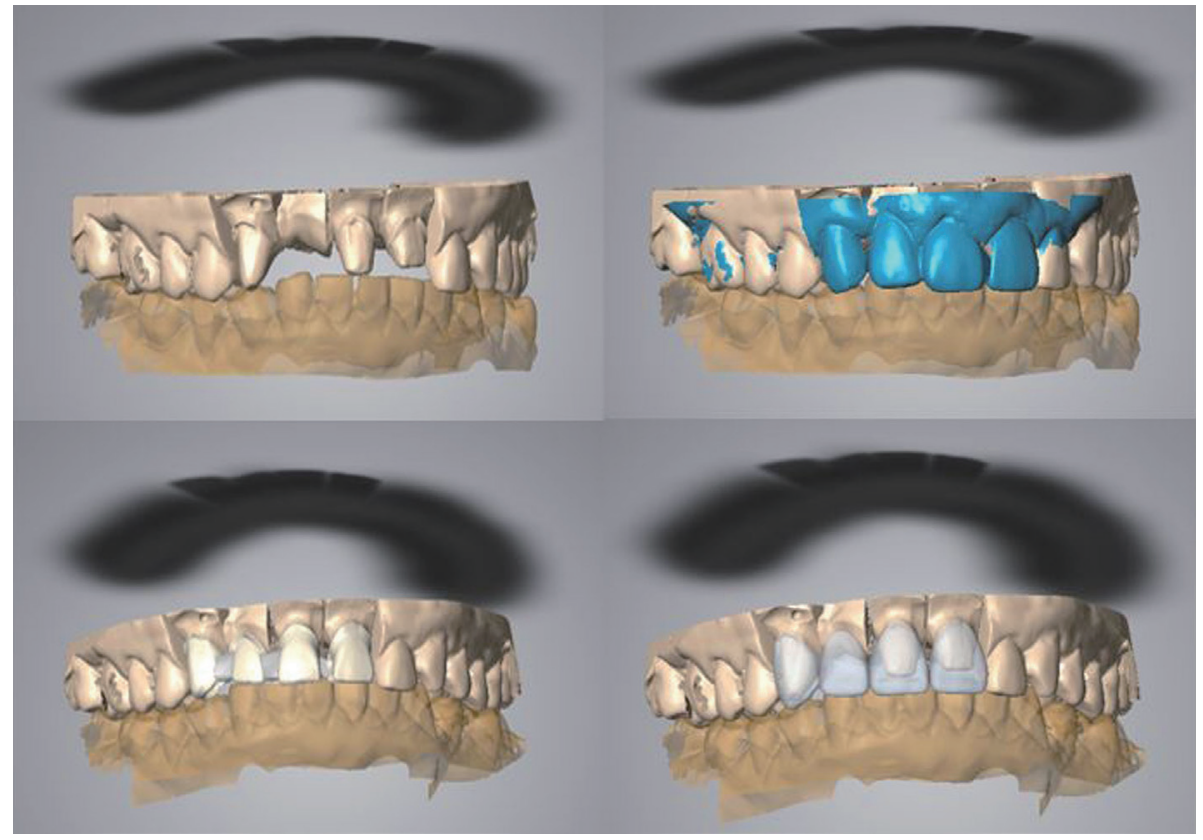

Fig. 18. CAD image of coping design using scanned and superimposed image.
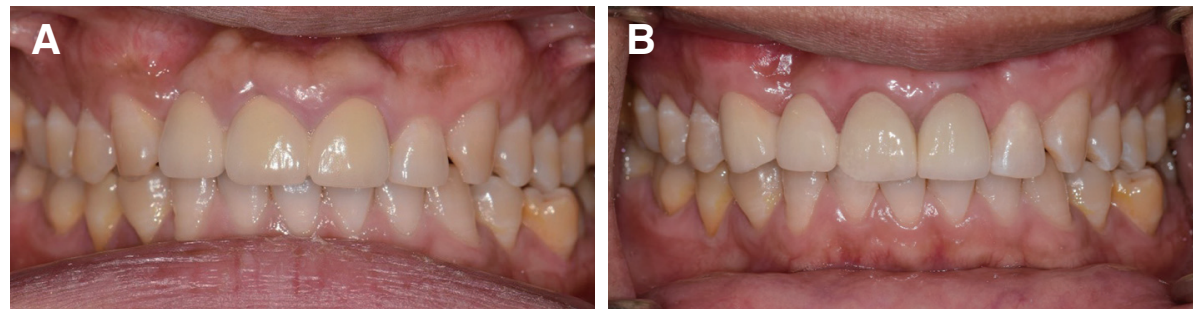

Fig. 19. Intraoral image of frontal view. (A) Before treatment, (B) After treatment.
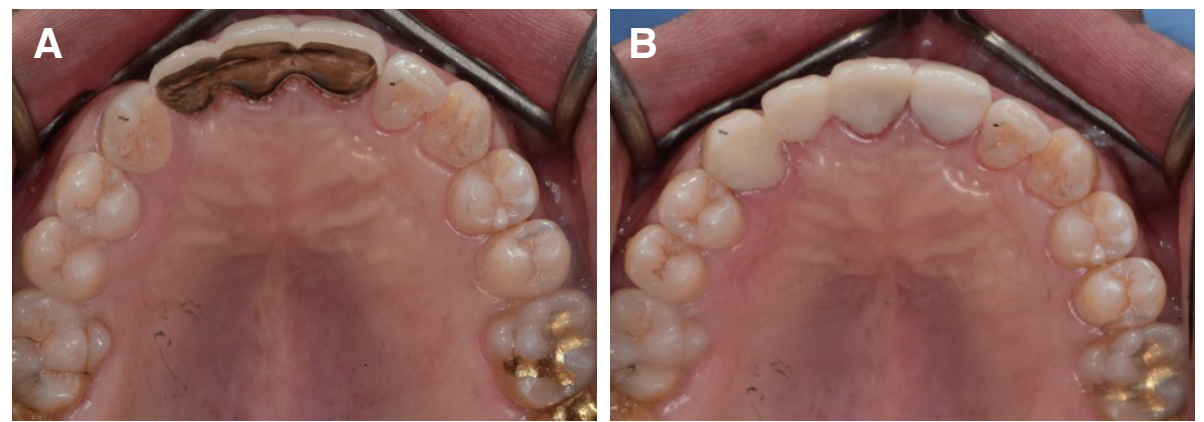

Fig. 20. Intraoral view of occlusion. (A) Before treatment, (B) After treatment view.

여 지르코니아 블록(Lava ${ }^{\mathrm{TM}}$ Zirconia Blocks, 3M, Minnesota, USA)을 가공하여 코핑을 제작하였고, 코핑을 구 강 내에 시적해 보았다. 도재(Creation porcelain, Zensen Dental, North Haven, USA)를 축성하여 \#11, 13 치아를 지대치로 하는 3 본 전부 도재관과 \#21 치아를 지대치로
하는 전부 도재관을 제작하여 구강 내에 장착하였다. 치 은의 비심미적인 착색이 개선되었으며, \#22 치아의 길이 증가로 좌우의 부조화를 개선하였다(Fig. 19). 교합면 사 진을 보았을 때 큰 교합 변화 없이 구강 내 보철물을 장 착하였다(Fig. 20). 


\section{고찰}

상악 전치부는 심미적, 기능적 측면을 모두 만족시켜야 한다. 이를 만족시키기 위해서는 치아의 해부학적 형태 및 비율뿐 아니라 주변 연조직 및 경조직의 형태, 미소선 등 여러 가지 요소를 고려해야 한다.

치아와 안모와의 관계를 봤을 때 상악 중절치는 안모 의 정중선 및 순소대와 일치 하는 것이 좋지만, 이는 인구 의 $70 \%$ 정도에서만 일치한다. 치아와 안모의 정중선이 일치하면, 좌우 비대칭과 부조화에서 오는 일부 비심미적 인 면이 분산될 수 있다. ${ }^{6}$ 한편, 본 증례의 첫 번째 환자에 서는 안모의 정중선에 대해 상악 중절치의 중심선이 우 측으로 약 $1.2 \mathrm{~mm}$ 편향된 것을 알 수 있었다. 때문에 보 철 수복적으로 이를 해결하기에는 한계가 있었고, 치아 형태를 수정하는데 만족해야 했다. 반면에 두 번째 증례 의 환자의 경우, 안모의 정중선과 상악 중절치의 중심선 이 일치하여 바람직한 결과를 얻을 수 있었다.

치아뿐만 아니라 치은연의 형태 및 위치 이상도 상악 전치부의 심미에 많은 영향을 끼친다. 이를 해결하기 위 해 치관 연장술을 동반한 보철수복이 필요하기도 한다. 치관 연장술은 치조골정, 결체조직의 부착, 상피의 부착 위치, 치은치조 점막 경계에 따라 술식이 달라진다. ${ }^{7}$ 생물 학적 폭경인 $2.04 \mathrm{~mm}$ 를 침범하지 않으면서 치은 절제가 가능한 경우, Coslet's APE classification 중 "Type 1A" 에 해당하며, 이때는 골성형술 없이 치은절제술만으로 가능하다. ${ }^{8}$ 진단모형을 통한 분석 결과 첫 번째 증례 환 자의 경우, 치관 폭/길이 비율을 개선하기 위해서 약 0.5 $\mathrm{mm}$ 의 치은절제가 필요하였고, 두 번째 증례 환자의 경 우, \#22 치아의 길이 개선을 위해 약 $1 \mathrm{~mm}$ 의 치은절제가 필요하였다. 하지만 두 번째 증례 환자의 \#22 치아의 백 악법랑경계를 침범하지 않는 선에서 치은 절제술을 시행 하는 것이 보다 심미적일 것이라고 판단 되어 $0.5 \mathrm{~mm}$ 의 치은 절제를 결정하였다. Bone sounding 결과, 두 증례 모두에서 치은연에서 $3.5 \mathrm{~mm}$ 하방으로 치조골정이 위치 하는 것을 알 수 있었고, 이에 골성형술 없이 치은절제술 을 시행하였다.

과도한 치은 노출은 많은 환자들에서 비심미적인 미소 의 원인이 되는 요소 중 하나이다. 과도한 치은 노출은 미 소시 상악 전치부 전체 치아 및 치은이 모두 노출되는 경 우로써 Tjan 등의 연구에 따르면, 450 명의 20 - 30대 환 자들의 미소선을 분석한 결과 $7 \%$ 남성과 $14 \%$ 의 여성에 서 과도한 치은 노출을 보였다. ${ }^{9}$ Lip-repositioning은 안
전하고 높은 만족도를 이끌어내며 과도한 치은 노출을 개선할 수 있는 술식이다. ${ }^{10} 13$ 명의 환자에 대해 과도한 치은 노출을 개선하고자 lip repositioning을 시행한 Silva 등의 연구에서 $92 \%$ 의 경우에서 매우 편안함을 느꼈으며 만족할만한 결과를 얻었다고 보고하였다. ${ }^{11}$ 본 증례의 첫 번째 환자 또한 심한 과도한 치은 노출을 나타내었으며, 치은절제술을 동반한 lip repositioning을 시행하였다. 1 년 후 검사 결과 환자는 매우 만족하였고, 개선된 미소를 보였다.

한편, 상악 전치부 치아는 길이와 폭의 비율이 0.75 0.8 을 이룰 때 심미적이라고 평가된다. ${ }^{3}$ 본 증례의 첫 번 째 환자는 상악 6전치가 0.9 - 1.0 정도의 비율을 보이며 다소 폭에 비해 길이가 짧은 치관 형태를 보였으며, 특히 상악 중절치의 절단연 위치가 일치하지 않아 다소 비심미 적인 형태를 가졌다. 두 번째 증례의 환자의 경우 \#22 치 아의 길이와 폭의 비율이 0.9 정도를 보였기 때문에 치관 길이를 증가시켜 이를 해결하고자 하였다.

치아의 형태뿐만 아니라 치아 자체의 질감이나 색상 또 한 비심미적인 외형을 가지는 이유가 된다. 반점치는 치 아형성기 동안에 치아가 불소에 노출되면서 법랑질의 Retzius 선조에 공극률이 증가하며 법랑질 표면이 불투명 하게 보이는 것이다. ${ }^{5}$ 본 증례의 첫 번째 환자는 상악 전치 부의 반점치로 인한 치아 변색을 보였으며, Dean's index ${ }^{5}$ 에 따르면, 상악 중절치의 "3-moderate and severe", 측 절치와 견치의 "2-mild"한 정도의 변색을 나타내고 있었 다. 전치부의 변색과 형태 수정을 위해 지르코니아를 코 핑으로 하는 완전 도재관을 계획하여 수복하였다.

현재 CAD/CAM의 발달로 강도 및 인성이 뛰어난 치 과용 지르코니아(Yttria stabilized Tetragonal Zirconia Polycrystal)가 고정성 보철물의 재료로써 널리 고려되고 있다. 하지만, 지르코니아 수복물의 교합 조정으로 인해 표면이 거칠어지는 경우 표면 연마를 하는 것이 까다로 우며, 이로 인한 물성의 저하 및 장기적인 보철물의 예후 에 끼치는 영향에 대해서는 명확하게 알려져 있지 않다. ${ }^{12}$ 때문에 교합조정은 최소화하는 것이 좋고, 이는 $\mathrm{CAD} /$ CAM system과 디지털 스캐너를 활용함으로써 개선될 수 있다. 본 증례에서는 두 환자 모두 비심미적이나 기능 적으로는 문제가 없는 자연치열 혹은 기존 수복물을 사 용하고 있었다. 불편감이 없었던 기존의 교합을 그대로 가져오면서 심미적인 부분은 개선하기 위하여 디지털 모 델 스캐너를 통해 납형 진단 모형과 지대치 주모형을 중 첩하였고, 지르코나아 블록을 가공함으로써 수복물을 
제작하였다.

본 증례들은 비심미적인 치은형태를 가진 상악 전치부 에서 납형 진단 모형을 통해 진단 및 치료계획을 수립하 여 치은절제술을 동반하고, 모델 스캐너와 $\mathrm{CAD} / \mathrm{CAM}$ system을 이용한 지르코니아를 코핑으로 하는 완전 도재 관 수복을 시행하였다. 그 결과 심미적, 기능적으로 만족 할만한 결과를 얻을 수 있었다.

\section{결론}

상악 전치부의 심미를 만족하기 위해서는 치아의 외형 뿐 아니라 치은연의 형태 및 위치까지 고려 하여야 한다. 본 증례에서는 치은절제술을 통한 치은 외형 및 치관 길 이 연장과 더불어 기존 교합을 그대로 재현해 주기 위해 모델 스캐너와 CAD/CAM system을 이용한 지르코니 아를 코핑으로 하는 완전 도재관을 제작하여 보철 치료 를 시행하였다. 이를 통해 우수한 심미적 결과와 기능적 으로도 만족스러운 결과를 얻을 수 있었다.

\section{ORCID}

Sang Yeon Han https://orcid.org/0000-0002-2631-0758

Jonghyuk Lee https://orcid.org/0000-0003-1976-4089

Seok Yeun Choi https://orcid.org/0000-0001-9277-959X

\section{References}

1. Magne P, Gallucci GO, Belser UC. Anatomic crown width/length ratios of unworn and worn maxillary teeth in white subjects. J Prosthet Dent 2003;89: 453-61.

2. Dong JK, Jin TH, Cho HW, Oh SC. The esthetics of the smile: a review of some recent studies. Int J
Prosthodont 1999;12:9-19.

3. Radia S, Sherriff M, McDonald F, Naini FB. Relationship between maxillary central incisor proportions and facial proportions. J Prosthet Dent 2016; 115:741-8.

4. Marcuschamer E, Tsukiyama T, Griffin TJ, Arguello E, Gallucci GO, Magne P. Anatomical crown width/length ratios of worn and unworn maxillary teeth in Asian subjects. Int J Periodontics Restorative Dent 2011;31:495-503.

5. Sherwood IA. Fluorosis varied treatment options. J Conserv Dent 2010;13:47-53.

6. Ahmad I. Anterior dental aesthetics: dentofacial perspective. Br Dent J 2005;199:81-8.

7. Lee EA. Esthetic Crown Lengthening: Contemporary Guidelines for Achieving Ideal Gingival Architecture and Stability. Curr Oral Health Rep 2017;4: $105-11$.

8. Al-Harbi F, Ahmad I. A guide to minimally invasive crown lengthening and tooth preparation for rehabilitating pink and white aesthetics. Br Dent J 2018;224:228-34.

9. Tjan AH, Miller GD, The JG. Some esthetic factors in a smile. J Prosthet Dent 1984;51:24-8.

10. Mahn DH. Elimination of a "Gummy Smile" With Crown Lengthening and Lip Repositioning. Compend Contin Educ Dent 2016;37:52-5.

11. Silva CO, Ribeiro-Júnior NV, Campos TV, Rodrigues JG, Tatakis DN. Excessive gingival display: treatment by a modified lip repositioning technique. J Clin Periodontol 2013;40:260-5.

12. Miyazaki T, Nakamura T, Matsumura H, Ban S, Kobayashi T. Current status of zirconia restoration. J Prosthodont Res 2013;57:236-61. 


\section{비심미적인 상악 전치부 치아 비율을 가지는 환자에서 치은 절제술을 동반한 전치부 심미수복 증례}

\section{한상연 ${ }^{1}$, 이종혁 ${ }^{1 *}$, 최석연 ${ }^{2}$}

${ }^{1}$ 단국대학교 치과대학 치과보철학교실

${ }^{2}$ 장백 치과기공소

상악 전치부는 심미적으로 민감한 부위이며, 치아 외형과 치은의 조화도 치료의 성공과 밀접한 관련이 있다. 이를 위해서 는 정확한 진단과 치료계획이 필수적이며, 필요 시 치아 주위 연조직에 대한 처치 등이 동반될 수 있다. 연조직 처치로서 외과적 치관연장술 중 하나인 치은절제술을 고려할 수 있으며 이를 통해 심미적인 보철 수복을 할 수 있다. 상악 전치부는 심미뿐 아니라 기능 또한 고려하여야 한다. 지대치 주모형과 순측만을 수정한 진단 납형 모형을 스캔 및 중첩하여 디자인 및 가공하면, 최소한의 교합조정을 통해 기존의 편안했던 교합을 재현해 줄 수 있다. 본 증례에서는 치은절제술 및 모형 중첩을 통해 심미 수복을 진행하였고, 그 결과 심미와 기능모두에서 환자의 만족도를 높였기에 이를 보고하는 바이다.

(구강회복응용과학지 2018;34(3):208-17)

주요어: 심미; 치은절제술; 진단 납형; 모형 중첩 